\title{
The Relation between Dietary Protein, Calcium and Bone Health in Women: Results from the EPIC-Potsdam Cohort
}

\author{
Cornelia Weikert ${ }^{\mathrm{a}}$ Dietmar Walter $^{\mathrm{a}}$ Kurt Hoffmann $^{\mathrm{a}}$ Anja Kroke ${ }^{\mathrm{b}}$ \\ Manuela M. Bergmann ${ }^{a}$ Heiner Boeing ${ }^{a}$

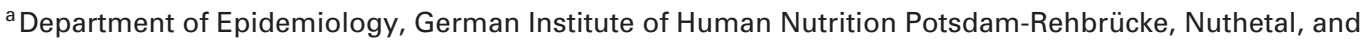 \\ ${ }^{\mathrm{b}}$ Research Institute of Child Nutrition, Dortmund, Germany
}

\section{Key Words}

Bone health $\cdot$ Broadband ultrasound attenuation .

Dietary proteins

\begin{abstract}
Background/Aims: The role of dietary protein in bone health is controversial. The objective of the present study was to examine the association between protein intake, dietary calcium, and bone structure measured by broadband ultrasound attenuation (BUA). Methods: Our analysis includes 8,178 female study participants of the European Prospective Investigation into Cancer and Nutrition (EPIC) Potsdam Study. Ultrasound bone measurements were performed on the right os calcis, and BUA was determined. Dietary intake was assessed by a standardized food frequency questionnaire. We applied linear regression models to estimate the association between dietary protein and BUA. Results: After multivariate adjustment, high intake of animal protein was associated with decreased BUA values $(\beta=-0.03 ; p=0.010)$ whereas high vegetable protein intake was related to an increased BUA ( $\beta=0.11 ; p=0.007$ ). The effect of dietary animal protein on BUA was modified by calcium intake. Conclusion: High consumption of protein from animal origin may be unfavourable, whereas a higher vegetable protein intake may be beneficial for bone health. Our re-
\end{abstract}

sults strengthen the hypothesis that high calcium intake combined with adequate protein intake based on a high ratio of vegetable to animal protein may be protective against osteoporosis.

Copyright $\odot 2005$ S. Karger AG, Basel

\section{Introduction}

Protein and calcium are major components of bone tissue and also play an active role in bone metabolism [1]. The protective effect of dietary calcium against osteoporosis is well established [2]. In contrast, the relevance of protein intake remains controversial in this context. $\mathrm{Nu}-$ merous studies have shown a positive association between dietary protein intake and urinary excretion of calcium $[3,4]$, and a link between a high protein intake and a greater risk of fracture has also been demonstrated [5]. These observations can be explained by an increased endogenous acid production secondary to high dietary protein, which triggers a buffering response by the bone ultimately leading to an increased bone resorption and decreased bone formation. This is especially true for protein from animal sources because of the high content of sulphur amino acids $[3,6]$. Diets high in protein from animal foods and low in base-forming components are common in industrialized societies and their effects on

\section{KARGER \\ Fax +4161306 1234 E-Mail karger@karger.ch} www.karger.com
(C) 2005 S. Karger AG, Basel 0250-6807/05/0495-0312\$22.00/0

Accessible online at:

www.karger.com/anm
Cornelia Weikert, MD, MPH

Department of Epidemiology, German Institute of Human Nutrition

Arthur-Scheunert-Allee 114-116

DE-14558 Nuthetal (Germany)

Tel. +4933200 88717, Fax +493320088721, E-Mail Weikert@mail.dife.de 
the acid-base homeostasis may even be intensified in the elderly because of the age-related decline in renal function [7].

On the other hand, bone loss may also relate to very low protein intake in the elderly. Moreover, results from epidemiological studies about the association of protein and bone mineral density (BMD), the classic parameter of bone health, are inconsistent [8]. The majority of published studies supports a positive association between a high dietary protein intake and BMD [9], which, given the effect of dietary protein on calcium balance, seems counter-intuitive. Studies investigating the association between protein intake and fracture risk are equally inconclusive, with some evidence for an increase in risk of fractures with higher protein intake, especially protein of animal origin $[10,11]$.

Growing evidence suggests that calcium and protein interact in terms of bone health, i.e., the potential harmful effect of high protein intake may be compensated for by an adequate calcium intake $[12,13]$. A ratio greater or equal to $20 \mathrm{mg}$ calcium per $1 \mathrm{~g}$ protein is considered sufficient for bone protection [14]. In epidemiological studies, an inverse association between protein intake and fracture risk was demonstrated specifically for subjects with comparatively high dietary calcium in relation to protein intake [15-17]. An increase of fracture risk with higher protein intake seems to occur if calcium intake is low, which may at least in part explain the inconsistent results of the studies published so far [18].

In this cross-sectional analysis, we aimed at investigating the association between bone health and protein intake. As broadband ultrasound attenuation (BUA) is considered to constitute an acceptable parameter for measuring bone health [19-21], we examined the association of protein intake, calcium intake, and BUA obtained from quantitative ultrasound bone measurements in a large population-based sample of German women.

\section{Methods}

\section{Study Population}

The European Prospective Investigation into Cancer and Nutrition (EPIC) Potsdam Study is part of the large-scale, Europeanwide prospective cohort EPIC study focusing on the relation between nutrition and chronic diseases, especially cancer [22]. The study was approved by the ethics committee of the federal state of Brandenburg, Germany, and written informed consent was obtained from all participants. Between 1994 and 1998, 27,548 participants (16,644 women, 10,904 men) aged 35-65 years were recruited in Potsdam and its surrounding communities. The recruitment process was based on general population registries. Study subjects were invited by mail to participate in the baseline examination [23]. Quantitative ultrasound (QUS) measurements of the os calcis were introduced into the recruitment procedures of female participants in 1996, so that QUS data were available for 9,802 women.

\section{Quantitative Ultrasound Measurement}

QUS measurement was performed on the right os calcis using Achilles Plus Ultrasound Densitometer (Lunar Corporation, Madison, Wisc., USA). Trained and quality-monitored personnel performed the measurements according to manufacturer instructions [24]. We measured BUA in decibel/megahertz, which is defined as the slope of the signal attenuation versus the frequency curve in the usually assessed range of $0.1-1 \mathrm{MHz}$ [25]. In a substudy, 11 women were measured 10 times within 3 weeks, and an intra-person coefficient of variation of $1.47 \%$ was obtained for BUA.

\section{Assessment of Dietary Intake, Lifestyle Characteristics and}

other Covariates

Dietary intake information was assessed with a self-administered scanner-readable food frequency questionnaire that included questions on frequency and portion size of 148 food items eaten during the previous year [26]. The FFQ was sent to the study participants prior to the visit in the study centre. Nutrients were calculated using the German Food Composition Table (BLS II.3) [27]. Reproducibility and relative validity of the FFQ were tested during the recruitment in the Potsdam cohort [26].

Measurements of body weight and height were performed by trained and quality-monitored personnel with participants wearing no shoes and only light underwear [28]. Body mass index (BMI) was calculated as body weight divided by body height squared. Information on social status, smoking habits, physical activity, medication, and reproductive, occupational and medical history was obtained by a self-administered questionnaire and a computerguided personal interview [23]. Menopausal status was defined based on self-reported information about menstrual status/history, type of menopause (natural or surgical), use of oral contraceptives and hormone replacement therapy, or by using age cut-offs as defined for the EPIC cohort. Physical activity level was calculated from the self-reported duration and intensity of physical activity (including, for instance, walking, cycling, gardening), taking in account the metabolic equivalents [29]. Self-reported medication over the past 4 weeks prior to the baseline interview was used to identify users of glucocorticoids and specific drugs against osteoporosis. Persons who reported calcium supplement use of longer than 1 month during the past year prior to the baseline interview were classified as calcium supplement users.

\section{Statistical Analysis}

From the total female study population $(\mathrm{n}=9,802), 1,624$ women were excluded due to: missing BUA values $(\mathrm{n}=91)$, age at baseline below 35 years $(n=157)$, uncertain menopausal status $(n=$ $922)$, surgical menopause $(n=326)$, use of glucocorticoids $(n=17)$ or medication for the treatment of osteoporosis $(n=30)$, both known to affect bone metabolism [30], and missing covariate data $(\mathrm{n}=81)$. The final data set comprised 8,178 women for analysis.

Multivariate linear regression models were used to estimate relations between BUA and protein intake, with BUA (continuous) being the dependent variable. In these models, dietary protein was characterized by several independent variables including total pro- 
Table 1. Linear regression parameter estimates of $\mathrm{BUA}^{1}(\mathrm{~dB} / \mathrm{MHz})$ at the os calcis, including interaction terms of calcium and protein factors $(\mathrm{n}=8,178)$

\begin{tabular}{lclll}
\hline Variable & $\beta$ & $\mathrm{SE}(\beta)$ & $\mathrm{p}$ value & $\mathrm{R}^{2}$ \\
\hline Model 1 & & & & \\
$\quad$ Calcium & 2.74 & 0.96 & 0.004 & 0.118 \\
$\quad$ Calcium-protein interaction term & -0.022 & 0.009 & 0.014 & \\
$\quad$ Total protein & -0.009 & 0.015 & 0.529 & \\
Model 2 & & & & \\
$\quad$ Calcium & 3.13 & 1.13 & 0.006 & 0.119 \\
$\quad$ Calcium-animal protein interaction term & -0.027 & 0.011 & 0.017 & \\
$\quad$ Animal protein & -0.006 & 0.016 & 0.713 & \\
$\quad$ Calcium-vegetable protein interaction term & 0.020 & 0.039 & 0.609 & \\
$\quad$ Vegetable protein & 0.091 & 0.053 & 0.088 & \\
Model 3 & & & & \\
$\quad$ Calcium & 3.48 & 0.89 & $<0.001$ & 0.119 \\
$\quad$ Calcium-animal protein interaction term & -0.024 & 0.010 & 0.017 & \\
$\quad$ Animal protein & -0.009 & 0.016 & 0.574 & \\
$\quad$ Vegetable protein & 0.107 & 0.042 & 0.010 & \\
\hline
\end{tabular}

${ }^{1}$ All models are adjusted for vitamin D, magnesium, potassium, calcium supplement use, age, educational level, hormone replacement therapy, smoking, alcohol consumption, BMI, physical activity and menopausal status. tein, animal protein, vegetable protein, and the ratio of animal to vegetable protein. Protein intake was also retained in continuous form. Models were adjusted for several covariates, such as dietary calcium intake (continuous), vitamin D intake (continuous), magnesium intake (continuous), potassium intake (continuous), calcium supplement use (yes/no), age (continuous), educational attainment (unskilled and skilled, technical school, university degree), hormone replacement therapy (yes/no), smoking status (non-smoker, ex-smoker, current smoker), alcohol consumption (continuous), BMI (continuous), physical activity (continuous), postmenopausal status (yes/no) and total energy intake (continuous).

To evaluate a putative interaction between calcium and protein, multiplicative interaction terms of calcium and total protein, calcium and animal protein, and calcium and vegetable protein were included and tested in the fully adjusted linear regression models. In addition, we applied a specific regression model (table 1; model 3 ) to better illustrate the complex relation between dietary calcium, dietary protein and BUA. In this model, the mean values of all covariates were applied, and BUA values were predicted for different amounts of calcium, vegetable and animal protein intake.

All statistical analyses were performed using SAS software, version 8.02 (SAS Institute, Cary, N.C., USA).

\section{Results}

General characteristics of the study population are presented in table 2. Women ranged in age from 35 to 67 years. Mean BUA was $110.4 \mathrm{~dB} / \mathrm{MHz}$.

Total protein intake was positively associated with BUA in the crude linear regression model (data not shown). After adjustment for dietary calcium, age, BMI,
Table 2. General characteristics of the women $(n=8,178)$ participating in the EPIC Potsdam Study, Germany

\begin{tabular}{ll}
\hline Variable & Values \\
\hline BUA, dB/MHz & $110.4 \pm 10.3$ \\
Age, years & $47.8 \pm 9.3$ \\
BMI, kg/m ${ }^{2}$ & $25.6 \pm 4.6$ \\
Physical activity level & $1.82 \pm 0.35$ \\
Smoking status, \% & \\
$\quad$ Non-smoker & 56.9 \\
Ex-smoker & 24.8 \\
Current smoker & 18.3 \\
Educational attainment, \% & \\
$\quad$ Unskilled or skilled & 41.8 \\
Technical college & 28.7 \\
University degree & 29.5 \\
Menopausal status, \% & \\
Pre/Peri & 60.3 \\
Post & 39.7 \\
Hormone replacement therapy, \% & 18.8 \\
Calcium supplement user, \% & 6.3 \\
Energy and nutrients intake & \\
$\quad$ Total energy, kJ/day & $8,000 \pm 2,398$ \\
Dietary calcium intake, mg/day & $799 \pm 344$ \\
Dietary potassium intake, g/day & $2.80 \pm 0.79$ \\
Dietary magnesium intake, g/day & $0.31 \pm 0.08$ \\
Ratio of animal to vegetable protein intake & $1.87 \pm 0.65$ \\
Dietary vitamin D intake, $\mu$ g/day & $3.63 \pm 2.69$ \\
Total protein intake, g/day & $67.9 \pm 20.1$ \\
$\quad$ Dietary vegetable protein intake, g/day & $24.2 \pm 6.9$ \\
Alcohol consumption, g/day & $8.8 \pm 11.1$ \\
& \\
& \\
&
\end{tabular}

Unless otherwise stated, results are means \pm SD. 
Table 3. Linear regression parameter estimates for $\mathrm{BUA}^{1}(\mathrm{~dB} / \mathrm{MHz})$ at the os calcis $(\mathrm{n}=8,178)$
Table 4. Predicted BUA values for different combinations of calcium and protein intake ${ }^{1}$

\begin{tabular}{lcccc}
\hline Variable & $\beta$ & $\mathrm{SE}(\beta)$ & $\mathrm{p}$ value & $\mathrm{R}^{2}$ \\
\hline Model 1 & & & & 0.117 \\
$\quad$ Total protein & -0.03 & 0.013 & 0.017 & \\
$\quad$ Model 2 & & & & 0.119 \\
$\quad$ Animal protein & -0.03 & 0.012 & 0.010 & \\
$\quad$ Vegetable protein & 0.11 & 0.042 & 0.007 & \\
$\quad$ Model 3 & & & & 0.135 \\
$\quad$ Protein ratio, animal to vegetable & -1.12 & 0.31 & $<0.001$ & \\
$\quad$ Total protein & 0.014 & 0.017 & 0.41 & \\
\hline
\end{tabular}

${ }^{1}$ All models are adjusted for calcium, vitamin D, magnesium and potassium intake, calcium supplement use, age, educational level, hormone replacement therapy, smoking, alcohol consumption, BMI, physical activity and menopausal status.

\begin{tabular}{|c|c|c|c|c|c|c|c|c|}
\hline \multirow{2}{*}{$\begin{array}{l}\text { Animal } \\
\text { protein } \\
\text { g/day }\end{array}$} & \multirow{2}{*}{$\begin{array}{l}\text { Vegetable } \\
\text { protein } \\
\text { g/day }\end{array}$} & \multirow{2}{*}{$\begin{array}{l}\text { Ratio } \\
\mathrm{A} / \mathrm{V}\end{array}$} & \multicolumn{6}{|c|}{ Calcium intake, g/day } \\
\hline & & & 0.4 & 0.6 & 0.8 & 1.0 & 1.2 & 1.4 \\
\hline 45 & 25 & 1.8 & 109.6 & 110.1 & 110.6 & 111.1 & 111.6 & 112.0 \\
\hline 70 & 1 & 70 & 106.6 & 107.0 & 107.3 & 107.7 & 108.1 & 108.4 \\
\hline 60 & 10 & 6 & 107.8 & 108.2 & 108.6 & 109.0 & 109.4 & 109.8 \\
\hline 50 & 20 & 2.5 & 109.0 & 109.5 & 109.9 & 110.4 & 110.8 & 111.3 \\
\hline 40 & 30 & 1.33 & 110.3 & 110.8 & 111.2 & 111.8 & 112.3 & 112.9 \\
\hline 30 & 40 & 0.75 & 111.5 & 112.1 & 112.6 & 113.2 & 113.7 & 114.4 \\
\hline 20 & 50 & 0.4 & 112.8 & 113.4 & 113.9 & 114.6 & 115.1 & 115.8 \\
\hline 10 & 60 & 0.67 & 114.0 & 114.7 & 115.3 & 116.0 & 116.6 & 117.3 \\
\hline 0 & 70 & 0 & 115.3 & 116.0 & 116.7 & 117.4 & 118.1 & 118.8 \\
\hline
\end{tabular}

BUA was predicted by application of Model 3 (table 1) for different levels of calcium, animal and vegetable intake.

$\mathrm{A} / \mathrm{V}=$ Animal $/$ vegetable protein .

${ }^{1}$ All covariates (vitamin D, magnesium, potassium, calcium supplement use, age, educational level, hormone replacement therapy, smoking, alcohol consumption, BMI, physical activity and menopausal status) were set to their mean in the linear regression model. physical activity, dietary vitamin $\mathrm{D}$, dietary magnesium, dietary potassium, calcium-supplement use, educational attainment, HRT use, menopausal status, smoking, alcohol consumption and total energy intake the relation of total protein intake to BUA became inverse. For every $1 \mathrm{~g} /$ day increase in vegetable protein intake, a significant increase in BUA by $0.11 \mathrm{~dB} / \mathrm{MHz}$ was observed, whereas for an equal increase in animal protein intake, BUA decreased by $0.03 \mathrm{~dB} / \mathrm{MHz}$ (table 3 ).

Table 1 depicts results, including interactions between calcium and protein. Using multiplicative interaction terms for animal and vegetable protein in model 2 , the calcium-animal protein interaction term was statistically significant, whereas the interaction between calcium and vegetable protein was not significant.

The complex relation between calcium intake and protein intake is illustrated in table 4. Increase in BUA values was observed with increasing calcium intake for varying animal-to-vegetable protein ratios. However, the positive effect of calcium on BUA was less pronounced with higher ratios of animal to vegetable protein than with lower ratios. Moreover, the data in the columns of the table demonstrate that increasing consumption of vegetable and decreasing consumption of animal protein were associated with increasing BUA values irrespective of the calcium intake. 


\section{Discussion}

In this cross-sectional analysis, we observed a strong positive association between calcium intake and BUA in German women. Though a weak inverse association was seen between total protein intake and BUA, separate analyses for animal protein and vegetable protein revealed that the relation between protein consumption and BUA is more complex. While intake of protein from vegetable sources was positively related to BUA, consumption of animal protein was inversely associated with this parameter. Strengthening these observations, the ratio of animal to vegetable protein was negatively correlated with BUA; that is, high BUA values were measured in women whose total protein intake predominantly consisted of protein from vegetable sources.

Before potential implications of these results will be discussed, it is important to note the limitations of our study. Due to the cross-sectional study design, the associations between diet and bone health cannot be investigated prospectively, limiting the validity of our observations. However, the applied food frequency questionnaire assessed the diet over the past 12 months, which is unlikely to be biased by the studied outcome (BUA). Though we controlled for known risk factors of osteoporosis, we cannot exclude residual confounding. In this context, it is also noteworthy that detailed information about the amounts of calcium consumed through supplements is missing. However, results did not change significantly when mineral supplement users were excluded.

In our study, BUA derived from QUS measurements was used as marker of bone health. To our knowledge, this is the first study on the relationship between dietary protein and BUA, since previous studies on the topic applied BMD or fracture risk as parameters for bone health. Several studies have shown that site-specific measurements of BUA and BMD at the os calcis are sufficiently correlated $(r=0.68-0.86)[21,31]$. Theory suggests that BUA is influenced by bone density and bone microarchitecture [19], and when combined with speed of sound may detect bone fragility equally well as BMD [19]. On the other hand, the two parameters, BUA and BMD, may reflect different aspects of bone health. There is some evidence that QUS can give BMD-independent information on fracture risk [19, 31]. QUS measurements, however, still detect osteoporosis less reliably than BMD. Thus our results may not be readily comparable with other studies using BMD or fracture risk as the main outcome variable. Moreover, bone health is influenced by a variety of factors including age, smoking status, physical activity, BMI, and others. These factors may affect BUA and BMD in different ways, which may in part explain conflicting results [19, 32]. On the other hand, the population-based sample, the large number of participants and the data quality provided by the standardized procedures of the baseline examination [28] are among the strengths of our study.

Our results suggest that dietary vegetable protein may play a role in maintaining bone health. Vegetable food consumption was demonstrated to constitute an independent negative predictor for the worldwide incidence of hip fracture [11]. In addition, high consumption of fruit and vegetables was positively associated with BMD in both women [33-35] and men [36]. Altogether these results appear to support our findings. On the other hand, it cannot be ruled out that other substances, such as alkaline-producing dietary components, and not the protein per se are responsible for the observed effects. Moreover, others have reported results that contradict our observations $[15,37]$.

The negative effect of animal protein intake on bone health demonstrated in our study is in line with other studies reporting an increase in fracture risk with higher consumption of animal protein $[10,11,38]$. In contrast, high intake of animal protein was also related to a decreased risk of bone fractures [15] and increased BMD [37]. Thus the effects of dietary animal protein on bone health are still not unequivocal.

In contrast to our finding of an inverse association between the animal-to-vegetable protein ratio and BUA, two previous studies reported no such association [37, 39]. On the other hand, a high ratio was shown to increase the rate of bone loss and fracture risk in postmenopausal women [40]. Taken together, data on this issue remain inconclusive. In addition, an animal-to-vegetable protein ratio is difficult to interpret, as the varying amounts of intake may still give the same ratio. Finally, it may be the ratio between foods of animal versus vegetal origin rather than the protein ratio that is most relevant for maintaining bone health.

The interaction of dietary calcium and protein with regard to bone health has been described in several studies [14, 18, 41]. We identified an effect modification of protein, especially animal protein, by calcium. While the main effect of calcium on BUA was independent of the calcium-protein interaction, the opposite was observed for protein. According to our results, the detrimental effects of animal protein on BUA can be compensated for, at least in part, by a high calcium intake. Thus, the negative influence of animal protein on bone health may be 
pronounced in connection with low calcium intake. However, these interactions are very complex and far from sufficiently understood.

In conclusion, our analysis supports previous epidemiological evidence for a prominent role of dietary calcium in bone health. Our findings indicate that excessive protein intake from animal sources leading to an increased ratio of animal to vegetable protein compromises bone health, particularly if calcium intake is low. Nevertheless, the role of protein seems to be complex and may depend on other dietary components [42]. Further studies into mechanisms underlying the relationships between protein and bone health may improve our understanding of epidemiological data.

\section{Acknowledgements}

The authors thank all interviewers of the EPIC Potsdam Study for their work in data assessment and all study participants for their cooperation. The study was supported in part by the Federal Ministry of Education, Science, and Technology, Germany, grant No. 01 EA 9401; by the 'Europe against Cancer Programme' of the European Community, grant No. SOC 95201408 05F02. This study was in part supported by the Danone Institute.

\section{References}

1 Dawson-Hughes B: Interaction of dietary calcium and protein in bone health in humans. $\mathrm{J}$ Nutr 2003; 133:852S-854S.

2 Brown JP, Josse RG: 2002 clinical practice guidelines for the diagnosis and management of osteoporosis in Canada. CMAJ 2002;167(10 suppl):S1-S34.

3 Lemann J Jr: Relationship between urinary calcium and net acid excretion as determined by dietary protein and potassium: A review. Nephron 1999;81:18-25.

4 Kerstetter JE, O’Brien KO, Insogna KL: Low protein intake: The impact on calcium and bone homeostasis in humans. J Nutr 2003;133: 855S-861S.

$>5$ Rizzoli R, Ammann P, Chevalley T, Bonjour JP: Protein intake and bone disorders in the elderly. Joint Bone Spine 2001;68:383-392.

6 Buclin T, Cosma M, Appenzeller M, Jacquet AF, Decosterd LA, Biollaz J, Burckhardt P: Diet acids and alkalis influence calcium retention in bone. Osteoporos Int 2001;12:493499

7 Bushinsky DA: Acid-base imbalance and the skeleton. Eur J Nutr 2001;40:238-244.

$>8$ Ginty F: Dietary protein and bone health. Proc Nutr Soc 2003;62:867-876.

-9 Rizzoli R, Bonjour JP: Dietary protein and bone health. J Bone Miner Res 2004; 19:527531.

$\checkmark 10$ Abelow BJ, Holford TR, Insogna KL: Crosscultural association between dietary animal protein and hip fracture: A hypothesis. Calcif Tissue Int 1992;50:14-18.

11 Frassetto LA, Todd KM, Morris RC Jr, Sebastian A: Worldwide incidence of hip fracture in elderly women: Relation to consumption of animal and vegetable foods. J Gerontol A Biol Sci Med Sci 2000;55:M585-M592.

12 Whiting SJ, Boyle JL, Thompson A, Mirwald RL, Faulkner RA: Dietary protein, phosphorus and potassium are beneficial to bone mineral density in adult men consuming adequate dietary calcium. J Am Coll Nutr 2002;21:402409.
13 Teegarden D, Lyle RM, McCabe GP, McCabe LD, Proulx WR, Michon K, Knight AP, Johnston CC, Weaver CM: Dietary calcium, protein, and phosphorus are related to bone mineral density and content in young women. Am J Clin Nutr 1998;68:749-754.

14 Massey LK: Does excess dietary protein adversely affect bone? Symposium overview. J Nutr 1998;128:1048-1050.

15 Munger RG, Cerhan JR, Chiu BC: Prospective study of dietary protein intake and risk of hip fracture in postmenopausal women. Am J Clin Nutr 1999;69:147-152.

16 Johnell O, Gullberg B, Kanis JA, Allander E, Elffors L, Dequeker J, Dilsen G, Gennari C, Lopes Vaz A, Lyritis G, et al: Risk factors for hip fracture in European women: The MEDOS Study. J Bone Miner Res 1995;10:18021815 .

17 Kanis J, Johnell O, Gullberg B, Allander E, Elffors L, Ranstam J, Dequeker J, Dilsen G, Gennari C, Vaz AL, Lyritis G, Mazzuoli G, Miravet L, Passeri M, Perez Cano R, Rapado A, Ribot C: Risk factors for hip fracture in men from southern Europe: The MEDOS study. Osteoporos Int 1999;9:45-54.

>18 Meyer HE, Pedersen JI, Loken EB, Tverdal A: Dietary factors and the incidence of hip fracture in middle-aged Norwegians. A prospective study. Am J Epidemiol 1997;145:117-123.

19 Gonnelli S, Cepollaro C: The use of ultrasound in the assessment of bone status. J Endocrinol Invest 2002;25:389-397.

20 Gregg EW, Kriska AM, Salamone LM, Roberts MM, Anderson SJ, Ferrell RE, Kuller LH, Cauley JA: The epidemiology of quantitative ultrasound: A review of the relationships with bone mass, osteoporosis and fracture risk. Osteoporos Int 1997;7:89-99.

-21 He YQ, Fan B, Hans D, Li J, Wu CY, Njeh CF, Zhao S, Lu Y, Tsuda-Futami E, Fuerst T, Genant HK: Assessment of a new quantitative ultrasound calcaneus measurement: Precision and discrimination of hip fractures in elderly women compared with dual X-ray absorptiometry. Osteoporos Int 2000;11:354-360.
22 Riboli E: The European Prospective Investigation into Cancer and Nutrition (EPIC): plans and progress. J Nutr 2001;131:170S-175S.

23 Boeing H, Korfmann A, Bergmann MM: Recruitment procedures of EPIC Germany. European Investigation into Cancer and Nutrition. Ann Nutr Metab 1999;43:205-215.

$\checkmark 24$ Kroke A, Klipstein-Grobusch K, Bergmann MM, Weber K, Boeing H: Influence of body composition on quantitative ultrasound parameters of the os calcis in a population-based sample of pre- and postmenopausal women. Calcif Tissue Int 2000;66:5-10.

25 Langton CM, Palmer SB, Porter RW: The measurement of broadband ultrasonic attenuation in cancellous bone. Eng Med 1984;13:89-91.

26 Kroke A, Klipstein-Grobusch K, Voss S, Moseneder J, Thielecke F, Noack R, Boeing $\mathrm{H}$ : Validation of a self-administered food-frequency questionnaire administered in the European Prospective Investigation into Cancer and Nutrition (EPIC) Study: Comparison of energy, protein, and macronutrient intakes estimated with the doubly labeled water, urinary nitrogen, and repeated 24-hour dietary recall methods. Am J Clin Nutr 1999;70:439-447.

27 Dehne LI, Klemm C, Henseler G, HermannKunz E: The German Food Code and Nutrient Data Base (BLS II.2). Eur J Epidemiol 1999; 15:355-359.

28 Kroke A, Bergmann MM, Lotze G, Jeckel A, Klipstein-Grobusch K, Boeing $\mathrm{H}$ : Measures of quality control in the German component of the EPIC study. European Prospective Investigation into Cancer and Nutrition. Ann Nutr Metab 1999;43:216-224.

29 Boeing H, Weisgerber UM, Jeckel A, Rose HJ, Kroke A: Association between glycated hemoglobin and diet and other lifestyle factors in a nondiabetic population: Cross-sectional evaluation of data from the Potsdam cohort of the European Prospective Investigation into Cancer and Nutrition Study. Am J Clin Nutr 2000; 71:1115-1122. 
30 van Staa TP, Leufkens B, Cooper C: Bone loss and inhaled glucocorticoids. N Engl J Med 2002; 346:533-535.

- 31 Prins SH, Jorgensen HL, Jorgensen LV, Hassager $\mathrm{C}$ : The role of quantitative ultrasound in the assessment of bone: A review. Clin Physiol 1998;18:3-17.

-32 Frost ML, Blake GM, Fogelman I: Quantitative ultrasound and bone mineral density are equally strongly associated with risk factors for osteoporosis. J Bone Miner Res 2001;16:406416.

-33 Tucker KL, Hannan MT, Chen H, Cupples LA, Wilson PW, Kiel DP: Potassium, magnesium, and fruit and vegetable intakes are associated with greater bone mineral density in elderly men and women. Am J Clin Nutr 1999; 69:727-736.

34 New SA, Bolton-Smith C, Grubb DA, Reid DM: Nutritional influences on bone mineral density: A cross-sectional study in premenopausal women. Am J Clin Nutr 1997;65:18311839.
35 New SA, Robins SP, Campbell MK, Martin JC, Garton MJ, Bolton-Smith C, Grubb DA, Lee SJ, Reid DM: Dietary influences on bone mass and bone metabolism: Further evidence of a positive link between fruit and vegetable consumption and bone health? Am J Clin Nutr 2000;71:142-151.

36 Tucker KL, Chen H, Hannan MT, Cupples LA, Wilson PW, Felson D, Kiel DP: Bone mineral density and dietary patterns in older adults: The Framingham Osteoporosis Study. Am J Clin Nutr 2002;76:245-252.

37 Promislow JH, Goodman-Gruen D, Slymen DJ, Barrett-Connor E: Protein consumption and bone mineral density in the elderly: The Rancho Bernardo Study. Am J Epidemiol 2002;155:636-644.

38 Feskanich D, Willett WC, Stampfer MJ, Colditz GA: Protein consumption and bone fractures in women. Am J Epidemiol 1996;143: 472-479.
39 Hannan MT, Tucker KL, Dawson-Hughes B, Cupples LA, Felson DT, Kiel DP: Effect of dietary protein on bone loss in elderly men and women: The Framingham Osteoporosis Study. J Bone Miner Res 2000; 15:2504-2512.

40 Sellmeyer DE, Stone KL, Sebastian A, Cummings SR: A high ratio of dietary animal to vegetable protein increases the rate of bone loss and the risk of fracture in postmenopausal women. Study of Osteoporotic Fractures Research Group. Am J Clin Nutr 2001;73:118122 .

41 Dawson-Hughes B, Harris SS: Calcium intake influences the association of protein intake with rates of bone loss in elderly men and women. Am J Clin Nutr 2002;75:773-779.

42 Tucker KL, Hannan MT, Kiel DP: The acidbase hypothesis: Diet and bone in the Framingham Osteoporosis Study. Eur J Nutr 2001;40: 231-237. 